\title{
HEC MONTRẼAL
}

Institut

d'économie appliquée

Labour Supply and Taxes: New Estimates of the Responses of Wives to Husbands' Wages

Benoit DOSTIE

Lene KROMANN

Cahier de recherche $n^{\circ}$ IEA-12-02

February 2012 
Institut d'économie appliquée

HEC Montréal

3000 chemin de la Côte-Sainte-Catherine

Montréal (Québec) H3T 2A7

Canada

http://www.hec.ca/iea

iea.info@hec.ca

Copyright (C) 2012 HEC Montréal.

Tous droits réservés pour tous pays. Toute traduction ou toute reproduction sous quelque forme que ce soit est interdite sans l'autorisation expresse de HEC Montréal.

Les textes publiés dans la série des Cahiers de recherche HEC Montréal n'engagent que la responsabilité de leurs auteurs.

ISSN : 0825-8643 


\title{
LABOUR SUPPLY AND TAXES: NEW ESTIMATES OF THE RESPONSES OF WIVES TO HUSBANDS' WAGES $^{\S}$
}

\author{
BENOIT DOSTIE ${ }^{\dagger}$ AND LENE KROMANN $\ddagger$
}

\begin{abstract}
In this paper, we estimate income- and substitution- labour supply and participation elasticities for Canadian married women using data from the Survey of Labour and Income Dynamics 1996-2005. We use the Canadian Tax and Credit Simulator $(\mathrm{CTaCS})$ and detailed information on the structure of income at the household level to compute the marginal tax rates faced by each individual. We then use these marginal tax rates to compute net own-wage, spouse-wage, and non-labour income. We show how the magnitude of the estimated elasticities varies depending on whether net or gross wages and income are used in the estimation procedure, and quantify biases caused by using average instead of marginal tax rates. Finally, because marginal tax rates vary significantly over the sample, we use quantile regressions to compare elasticities at different points of the hours distribution. Overall, our results show that public policies now have, on average, less scope for influencing hours of work than 10 years ago. However, the quantile results show that wives working fewer hours per week are more sensitive to changes in their own or spouses' wages.
\end{abstract}

Date: February 28th 2011.

$\S$ We thank HRSDC for funding. All opinions and errors are our own.

† Institute of Applied Economics, HEC Montréal, University of Montréal, Montréal (Québec), H3T

$2 \mathrm{~A} 7$; IZA, CIRANO and CIRPÉE; benoit.dostie@hec.ca.

$\ddagger$ Copenhagen Business School - Center for Economic and Business Research Group (CEBR). 


\section{INTRODUCTION}

Labour supply elasticities are crucial for public policy. The number of hours worked is an important determinant of an economy's standard of living and it is important to understand how worked hours respond to wages and income. In particular, understanding how wives' hours of work and labour force participation decisions change in response to their husbands' wages allows us to better understand how changes in male earnings inequality translates into changes in family income inequality.

Given its importance, it is surprising that there is not much recent evidence on the size of labour supply elasticities for Canada. The available evidence mainly comes from a string of studies published from the late 1970s to the early 1990s. ${ }^{1}$ The most well-known of these studies is Nakamura, Nakamura, and Cullen (1979) who were the first to find evidence of a backward bending labour supply using data from the 1971 Census. This means that, past a certain level, an increase in wages will cause labour supply to fall, even though leisure becomes more expensive. ${ }^{2}$

Table 1 summarizes the available evidence on the magnitude of labour supply elasticities for Canadian women from previous Canadian studies. It is hard to draw definitive conclusions as the studies focus on different samples based on age, marital status, geographic location or income. However, they do provide reasonable ranges for both the wage- and income- elasticities. Estimates for the wage elasticity vary from -0.76 to 0.18. They are higher for single compared to married women and also higher for older women. The income elasticity is never positive and ranges from -0.50 to 0.00 .

The dearth of recent Canadian evidence on the magnitude of labour supply elasticities might be problematic because recent studies from the U.S. show large declines in labour supply elasticities over the past 20 years. In particular, Heim (2007) provides evidence that married women's labour supply elasticities fell by more than $60 \%$ over

\footnotetext{
${ }^{1}$ Another branch of the literature focuses on the impact of cost to work on the labour force participation decision, for example the cost of child daycare (Lefebvre and Merrigan (2008), Michalopoulos and Robins (2000), White (2001), Cleveland, Gunderson, and Hyatt (1996), Powell (2002), Powell (1997)). Chaykowski and Powell (1999) summarize this literature and conclude that diminishing the cost of daycare by $1 \%$ will increase labour force participation by $0.38 \%$.

${ }^{2}$ A finding confirmed and expanded upon by Nakamura and Nakamura (1981), Nakamura and Nakamura (1983), and Nakamura and Nakamura (1985).
} 
the 1978-2002 period. This finding holds for both hours and participation elasticities. ${ }^{3}$ Blau and Kahn (2007) also report similar results for how women's labour supply changed in reaction to their spouses' wages. ${ }^{4}$

This means that predictions of how hours of work or participation decisions would change following variations in wages or income based on previous elasticities estimates are likely to be well off the mark. In addition, if the recent findings from the U.S. also apply to Canada, the implication is that government policies affecting marginal tax rates will have a smaller distortionary effect on choices of hours of work than in the past, or that the possibility of raising labour supply through marginal tax changes is smaller.

The most recent Canadian study on this topic is Morissette and Hou (2008) who use census data to estimate how wives adjusted their labour supply in response to changes in husbands' wages over the 1980-2000 period. One focus of their study is using instrumental variable (IV) methods at the group level to take into account the possibility that husbands' wages are correlated with wives' unobservable preferences for work. In general, their estimated labour supply elasticities are much higher than recent estimates from the US and past estimates from Canada. Their OLS results show the cross-wages elasticity of unconditional hours varied between -0.15 and -0.26 during the 1980-90 period, and between -0.11 and -0.18 during the 1990-2000 period. Comparatively, IV methods applied at the group level yield corresponding elasticities varying between -0.39 and -0.88 for the $1980 \mathrm{~s}$, and between -0.17 and -0.78 for the $1990 \mathrm{~s}$. Finally, the evidence is mixed with respect to whether elasticities have diminished in a similar fashion in Canada and in the U.S.: Morissette and Hou (2008) find a decrease in elasticities over time using all methodologies except when applying an IV estimator on grouped data.

One concern with the conclusions of Morissette and Hou (2008) is that they did not use after-tax variables. Attempting to do so with Census data is bound to yield incorrect results because the available information on income and wages at the individual and household level is not detailed enough to compute the correct marginal tax

\footnotetext{
${ }^{3}$ The hours wage elasticity dropped by $60 \%$ ( 0.36 to 0.14$)$, the hours income elasticity by $70 \%(-0.053$ to -0.015$)$, the participation wage elasticity by $95 \%$ (0.66 to 0.03$)$, and the participation income elasticity by $60 \%(-0.13$ to -0.05$)$. One suggested explanation is that preferences toward work have changed across birth cohorts.

${ }^{4}$ Over the 1980-2000 period, married women's own wage elasticity decreased by $50 \%-56 \%$ and their cross-wage elasticity fell by $38 \%-47 \%$.
} 
rates, thus introducing measurement errors in the after-tax variables. ${ }^{5}$ Using after-tax variables is important for several reasons. First of all, when comparing their results to recent studies in the US, it should be noted that, whereas all working Canadians face the same tax tables with the exception of differences in provincial tax rates and allowable deductions, a wife's earnings in the US are taxed at the marginal rate which would apply to an additional dollar earned by the husband (this was first noted by Nakamura and Nakamura (1981)). ${ }^{6}$

Secondly, because of changes in marginal tax rates over the 1980-2000 period, a change in hours of work could lead to similar gross income changes but different net income changes. For example, marginal income tax rates have been slowly increasing throughout the 1980s and rapidly declining starting in 1995 (see Saez and Veall (2005), figure 8). This means that any percentage increase in wages in 2000 will yield a larger after-tax increase than in 1995, and, presumably, a larger labour supply response. Not taking into account changes in taxation would lead to the mistaken conclusion that there is an increase in labour supply elasticities.

Finally, a more subtle criticism is that wives with the same before-tax wage rate may well also have a different after-tax wage rate because of different annual hours of work, and differences in deductions and family non-labour income. Hence the estimated responses to changes in wages or income on annual hours of work will be biased because not taking into account marginal tax rates implicitly assumes that all wage changes are the same (see also Nakamura and Nakamura (1981)).

In this paper, we estimate labour supply and labour participation elasticities to ownwage, spouse-wage, and non-labour income for Canadian women using the Survey of Labour and Income Dynamics 1996-2005. We test the robustness of the estimates to various ways of computing after-tax wage and income. We also test the robustness of the estimates to various ways of taking into account endogeneity of wage and income. Finally, since tax rates vary with income, we estimate labour supply elasticities at various points of the hours distribution. The average effect may indeed hide more complex patterns. It could be that a change in wages affects individuals hours of work differently at the top than at the bottom of the hours distribution. ${ }^{7}$

\footnotetext{
${ }^{5}$ The only available information in the Census data are the individuals' contributions to the Canada/Quebec Pension Plans and to Employment Insurance and the type of income (employment income, investment income, self-employed income) received by the individuals.

${ }^{6}$ Nakamura and Nakamura (1981) summarize by saying that differences in the respective values of the estimated coefficients of the wage and income variables may simply reflect inter-country differences in the relationship of gross to disposable income.

${ }^{7}$ If one was interested only in estimating labour supply elasticities (and not on how they vary over time), there are a number of natural experiments from which to infer the causal impact of wages and
} 
When computing average elasticities with gross income variables over the 1996-2005 period, we obtain results that are very close to the OLS results obtained by Morissette and Hou (2008). However, when evaluating using the net income variables, we find the own- and spouse- wage elasticities to be much lower. This conclusion is robust to using an alternative estimation methodology in which we allow endogenous wage and income variables. Participation elasticities evaluated at net wage and income also decrease though less dramatically so. Over time, we find some evidence of a decline but since elasticities were very small to begin with, the possibility of further declines is limited.

The outline of the remainder of the paper is as follows. We discuss the data and descriptive statistics in section 2. This is followed in section 3 by the methodology. We present the results as well as robustness checks in section 4. A brief conclusion follows.

\section{DATA}

We use data from the Survey of Labour and Income Dynamics (SLID) conducted by Statistics Canada. This survey focuses on sub-samples of the more extensive Labour Force Surveys (LFS). ${ }^{8}$

Two main features distinguish the SLID from the LFS. First, each household in the SLID is surveyed for a period of six consecutive years. A new panel is introduced every three years so two panels always overlap. However, we do not use the longitudinal information in this paper. We could use the longitudinal features of the SLID to take into account fixed over time individual unobserved heterogeneity. However, in our robustness checks, we prefer to use IV methods that also deals with time-varying shocks to labour supply, and wages and income variables. We do use bootstrapped standard errors to take into account possible residual clustering. Second, the survey contains additional very detailed information on income for a large subset (more than $80 \%$ ) of individuals who agrees to match their records to information about their tax files from Revenue Canada. We use this detailed information on income to compute the marginal tax rates faced by the individual. ${ }^{9}$

income on hours of work that could be used over the 1996-2006 period. In particular, at the federal level, the government increased the number of tax brackets from three to four in 2001. There have also been a number of reforms at the provincial level. For example, see Sand (2005) for an examination of the 2001 reforms in British Columbia and Alberta.

${ }^{8}$ The LFS is akin to the Current Population Survey (CPS) in the U.S. and the SLID akin to the Panel Study of Income Dynamics (PSID). See Heim (2007) and Blau and Kahn (2007) for recent studies using the CPS to estimate labour supply elasticities.

${ }^{9}$ In our selected final sample, only $7 \%$ of our observation are missing information about their tax files. These observations are dropped from our analysis. 
From the SLID sample, we select married women aged between 25 and 55 so we do not have to deal with school-to-work or work-to-retirement transitions. We also exclude women who report being self-employed, or whose spouse is self-employed. We exclude all women who reported being in school full- or part-time at the time of the survey. Finally, we also drop observations if the spouse's wage is missing, immigrants or observations with the wage below $2 \$$ or over $200 \$$. We are left with a sample of 61 950 observations over 1996-2005.

Our dependent variable for the estimation of wage and income labour-supply elasticities is the total number of paid hours worked in all jobs occupied over the past year. This is computed as the sum of total usual hours minus non-remunerated hours. Our measure of wage is a composite index for all jobs occupied over the past year. It is computed as an average of the wages in all jobs weighted by the corresponding number of hours of each job. ${ }^{10}$ Note that these adjustments are made by Statistics Canada and the final variables are directly available from the SLID. Finally, as a measure of nonwork income, we use total family income and subtract the women's and their husbands' work income. This measure thus incorporates governmental transfers and income from assets.

Summary statistics on these variables (in current dollars for monetary variables) are presented in table 2. Over the last ten years, we observe married women's working hours to be trending up from 1,534 hours in 1996 to 1,668 hours in 2005, while their spouses' working hours are mostly constant around 2,000 hours of work per year. ${ }^{11}$ Interestingly, these relative movements are coherent with the relative changes in wages, as wives' wages increased from $\$ 14$ to $\$ 16$ per hour, while husband's wages increased more slowly from $\$ 20$ to $\$ 21$. Non-labour income is also quite stable across the 10 years but note that there is widespread variation in any given year.

The increases in hours of work and wages for wives are mirrored by a continuous increase in labour force participation shown in table 3. Labour force participation was already relatively high in 1996, at $81.4 \%$, but it still increased to almost $85 \%$ in 2005. Table 3 also presents summary statistics for the explanatory variables. In

\footnotetext{
${ }^{10}$ Usual wage or salary before taxes and other deductions. This includes tips, commissions, and bonuses but explicitly excludes paid overtime.

${ }^{11}$ The number of hours of work is larger than those reported in Morissette and Hou (2008). For 2000, we observe an average of 1584 hours, whereas Morissette and Hou (2008) obtain 1366. Their measure of hours of work is the product of weeks worked and usual weekly hours in May or June. This implies a difficult imputation problem for wives who reported working full time during the year but not usual hours for these two months. Our measure of non-wage income is also higher, possibly due to individuals underreporting income in census data. Morissette and Hou (2008) do not report average wages.
} 
all regressions, we use as control variables the age of the women (and age squared), a measure of health captured by a dummy variable equal to one if the women have any activity limitation, education (less than high school, high school, more than high school but less than university, university or higher), and dummy variables indicating the province of residence. This choice of covariates is made in order to stay as close as possible to Morissette and Hou (2008).

We compute after-tax wages and after-tax non-labour income using two different methods. Since the SLID contains detailed information from the women's tax records, we can easily compute average tax rates using before and after tax amounts for both variables. However, it is expected that these average tax rates will be poor approximations for the real marginal tax rates faced by the individual. For the computation of marginal tax rates, we use the CTaCS. ${ }^{12}$

The CTaCS is an open source package that simulates the Canadian personal income tax and transfer system (see Milligan (2008)). We use it to simulate the tax burden for all individuals in our sample. ${ }^{13}$ To obtain the marginal tax rate, we simulate an increase of $100 \$$ in wage income, compute a new tax burden, and use the difference with the previous tax liability divided by pre-simulation income. Given the very detailed data at our disposal, we are confident that we obtain a very close approximation of the real marginal tax rate faced by the individual.

\section{Methodology}

Our econometric method for estimating the labour supply elasticities has four steps similar to Heim (2007). ${ }^{14}$ In the first step we estimate the inverse Mills ratio $\left(\lambda_{i t}\right)$, using

\footnotetext{
${ }^{12}$ In the US, net money amounts are usually computed with the National Bureau of Economic Research (NBER) TAXSIM model (see for example Meyer (2002), Saez and Veall (2005), or Heim (2007)) or directly from tax table data (see Devereux (2004)). This last study is one example in which a robustness check is done comparing pre-tax and post-tax results, and they are found not to differ significantly. However, relying on tax tables makes it difficult to take into account itemized deductions so that the computed marginal tax rate faced by the individual is just an estimate of the true marginal tax rate faced.

${ }^{13}$ We provide the simulator with very detailed information on the income of the individual from his/her tax form, including (1) Union dues, (2) Daycare expenses, (3) Medical expenses, (4) Other deductions, (5) Other provincial credits, (6) Registered Pension Plan (RPP) contributions, (7) Employment or wage earnings, (8) Self-employment income, (9) Registered Retirement Savings Plan (RRSP) income, (10) Pension income, (11) Old Age Security (OAS) income, (12) Canada Pension Plan/Quebec Pension Plan (CPP/QPP) income (14) Employment insurance benefits, (15) Capital gains income, (16) Interest income, (17) Social assistance, (18) Workers compensation income, (19) Other income, and (20) Amount for spousal equivalent/eligible dependant. These computations also take into account the age, gender, province of residence and year.

${ }^{14}$ Standard errors of the estimated elasticities are bootstrapped to account for the sampling process and the multistage nature of the estimation method.
} 
Heckman's two step procedure. Specifically, we use a probit model to estimate the selection equation from which an estimate for $\lambda_{i t}$ can be computed for each individual $i$ at time $t$ if in the labour force as

$$
\widehat{\lambda_{i t}}=\frac{\Phi\left(\widehat{\delta}_{0}+\widehat{\delta}_{3} I_{i t}+\widehat{\delta} X_{i t}\right)}{\phi\left(\widehat{\delta}_{0}+\widehat{\delta}_{3} I_{i t}+\widehat{\delta} X_{i t}\right)}
$$

where $I_{i t}$ is the non-labour income in the family and $X_{i t}$ contains other variables that explain a person's participation in the labour market. The variables in $X_{i t}$ are a quadratic function of own and spouse age, education, province dummies, and a dummy variable indicating if the family has a preschool child. Of these variables, only the nonlabour income and the preschool children dummy variables are excluded from the wage equation. In this respect, our identifying assumptions are very similar to Heim (2007).

Since we do not observe the wages for the women that do not work, in the second step we impute the non-observed wages using the traditional regression imputation method. ${ }^{15}$ The wage is imputed based on a set of individual characteristics including human capital, $Z_{i t}^{w}$.

$$
\ln w_{i t}=\beta_{0}+\beta Z_{i t}^{w}+\rho_{w} \widehat{\lambda}_{i t}+u_{i t} .
$$

We also include the inverse Mills ratio computed in step one to correct for the endogenous labour force participation.

In the third step, we estimate the hours regression conditional on hours of work being positive:

$$
h_{i t}=\alpha_{0}+\alpha_{1} \ln w_{i t}^{w}+\alpha_{2} \ln w_{i t}^{h}+\alpha_{3} I_{i t}+\alpha Z_{i t}^{h}+\rho_{h} \widehat{\lambda}_{i t}+v_{i t},
$$

where $h_{i t}$ represents hours worked on a yearly basis, $w_{i t}^{w}$ is the wife's hourly wage, $w_{i t}^{h}$ is the husband's hourly wage, and $Z_{i t}^{h}$ are other variables explaining the number of hours worked. We also include non-labour income and the inverse Mills ratio.

There are a number of concerns about the estimation of equation 3.3 related to the possible endogeneity of wages. Three sources of endogeneity are usually put forward. First, observed hourly wages are often measured with error, as they are usually computed by dividing annual earnings by annual hours worked. Second, endogenous wages can also result from unobserved heterogeneity simultaneously driving labour

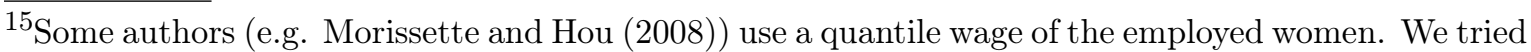
out many different imputation methods from quantile wages over regression imputation to multiple imputation by chained equations. While it made a noticeable difference going from quantile wages to regression imputation, the more advanced method did not change our results significantly. For this reason we chose to use regression imputation.
} 
force participation, hours of work decisions, and determining a worker's wage. Finally, in our particular case, the use of net wages introduces additional endogeneity concerns because the individual, in choosing their hours of work, also indirectly chooses the marginal tax rates they face.

The most common way to obtain unbiased estimates of the impact of wages on both outcomes is to use instrumental variables (IVs). A variety of variables have been used as instruments for wages, including higher degree polynomials of age and education. However, in those cases, it is hard to justify the exclusion restrictions. Lately, group averages or imputed wages have been used.

The idea behind using group averages as instruments is that measurement errors and unobserved factors correlated to both wages and hours of work are assumed to cancel out as the number of observations within a group gets large (see Angrist (1991)). However, the group averages IV method also has some major drawbacks. Firstly, the sample size has to be large enough to make the assumption that measurement errors or unobserved heterogeneity cancel out believable. In fact, the wage-hours correlation converges to the true causal relationship only as group size gets larger. This is not usually a problem with large-scale census data but it could be a problem with survey data like those we use here. Nevertheless, we present in the next section some robustness checks using group means as IVs.

One last possible instrument, imputed wages, should not depend on hours worked since they are not part of the covariates, and they are selection-corrected by including the inverse Mills ratio as an explanatory variable in the wage equation. The imputed wages should be highly correlated with wages and uncorrelated with the measurement errors. This is the method used by Heim (2007) who also tried out group means as an instrument and finally concludes that the results are remarkably similar to results in which wages are assumed to be exogenous. This is why we make this latter assumption in most of our empirical analysis. Our assumptions are thus very similar to Heim (2007), Blau and Kahn (2007) and Morissette and Hou (2008).

Finally, in the fourth step we estimate the labour force participation using a probit model, including among the explanatory variables the observed wages for working women and the imputed wages from equation (3.2) for non-working women:

$$
P\left(\text { Participation }_{i t}=1\right)=\Phi\left(\delta_{0}+\delta_{1} \ln \widehat{w}_{i t}^{w}+\delta_{2} \ln \widehat{w}_{i t}^{h}+\delta_{3} I_{i t}+\delta X_{i t}\right) .
$$

By including the spouse's wage and other income separately in the equation we can take into account that individual labour supply and consumption behaviour of husbands and wives is influenced differently by their own sources of income and the spouse's income. 
Furthermore, non-labour income can either be included combined for the family or separately for the wife and husband. Since we believe that non-labour income has the same effect on each individual's labour supply no matter where it comes from, we treat household non-labour income as a family variable. It should also be noted that we assume that the wife chooses her hours of work, taking the husband's choices as exogenous, which is why we can use a single equation for the hours equation of married women.

The estimation of equations (3.1) to (3.4) allows us to compute the elasticities in the following way. First the substitution- and income- elasticities of hours worked are computed as

$$
\begin{aligned}
\epsilon_{w t}^{h} & =\frac{\hat{\alpha}_{1}}{\bar{h}_{t}} \\
\epsilon_{I t}^{h} & =\frac{\hat{\alpha}_{2}}{\bar{h}_{t}} \bar{I}_{t}
\end{aligned}
$$

where $\bar{h}_{t}$ is average hours of work conditional on these being positive, and $\bar{I}_{t}$ is the average non-labour income for the same individuals.

The substitution- and income-elasticities of labour force participation are defined by

$$
\begin{aligned}
\epsilon_{w t}^{P} & =\frac{\hat{\delta}_{1} \bar{\phi}(.)}{\bar{p}_{t}} \\
\epsilon_{I t}^{P} & =\frac{\hat{\delta}_{2} \bar{\phi}(.)}{\bar{p}_{t}} \bar{I}_{t}
\end{aligned}
$$

where $\bar{\phi}($.$) is the average of \Phi$ defined in equation (3.4), and $\bar{p}_{t}$ is the average proportion of the sample in the labour force.

\section{Results}

The main results are presented in tables 4 and 5 . In table 4 , we present average elasticities for the 1996-2005 period. The most striking results are the diminishing elasticities when we first compare results obtained with gross to net amounts computed with average tax rates, and then compare results computed with net amounts obtained with marginal tax rates. For example, the hours own-wage elasticity first drops from 0.22 to 0.09 , and then from 0.09 to a final value of 0.03 when using marginal tax rates.

These average estimated values are all at the low end of the ranges given by Heim (2007) or Blau and Kahn (2007). They are also at the low end of the range provided by our summary of the studies using Canadian data and summarized earlier in table 1. These estimates are also lower than those provided by Morissette and Hou (2008). 
In fact, it should be noted that our average before tax elasticities broadly match the numbers provided by Morissette and Hou (2008) for 2000 (see Morissette and Hou (2008)'s Table 2), but when we use money variables computed with marginal tax rates, our estimated elasticities are much smaller. This underscores the importance of using the right tax rates to compute net amounts.

For the participation elasticities, the results are somewhat different. First of all, it makes a much smaller difference whether the own-wage participation elasticities are computed with before- or after-tax money variables. This limits the possibility of low wages acting as a sizeable barrier to labour force participation. For the spouse-wage participation elasticities, we observe a similar pattern as for the hours elasticity between the results computed using no taxes and average taxes. Specifically, it drops significantly from -0.06 to -0.02 . However, this pattern does not continue when comparing results computed with average taxes and marginal taxes. In fact, here the spouse-wage participation elasticities increase marginally, which is a similar pattern to the own-wage participation elasticities.

In table 5, we look at the evolution of these elasticities over the last 10 years in order to see if the same phenomenon of diminishing labour supply elasticities is present in Canada. Focusing first on hours elasticities, we do observe some decrease, although less dramatic than that in the U.S., probably because the elasticities we estimated for Canada were lower to begin with. However, it should be noted that these decreases are observed no matter which wage and income variables are used. In the case of participation elasticities, however, there does not seem to be much of a decrease: results are quite stable over the whole period except for an apparent decrease in the spousewage elasticity. ${ }^{16}$

4.1. Robustness Check. The main problem with the estimates from the previous subsection is the possible endogeneity of our wage variable. Remember that endogeneity in our framework comes mainly from two sources. First, it is probably the case that unobserved factors driving hours of work decisions are correlated with unobserved determinants of wages. Second, the average and marginal tax rates faced by the individual are directly determined by his or her income and hence by the hours of work.

\footnotetext{
${ }^{16}$ The results for the year 2000 can be directly compared to those from Morissette and Hou (2008) for the same year (see table 2). We obtain an own-wage elasticity of 0.27 compared to their own estimates varying between 0.03 to 0.17 depending on the wage imputation procedure used for non-working wives. They also report spouse-wage elasticities varying between -0.11 to -0.14 (compared to our -0.09 ) and non-labour income elasticities of -0.00 .
} 
One recent popular solution to this endogeneity problem is the use of group averages as instruments for wages (as proposed by Angrist (1991)). The idea being that unobserved factors will cancel out in the group. The difficulty is that one wants groups to be as homogeneous as possible while having as many individuals as possible in each group for this hypothesis to be believable. For example, Morissette and Hou (2008) are able to construct 300 groups defined by the interaction of province indicators, three husband's age categories, and 10 spouses' educational attainments.

We construct 48 groups each year, defined by the interaction of husbands' age (3 categories), combined education (4 categories), and geographic location (4 categories). Specifically, the age categories are 25-34 year old, 35-44 years old, and more than 44 years old (these are the same categories as Morissette and Hou (2008) and Blau and Kahn (2007)). However, our education categories are slightly less detailed than Morissette and Hou (2008). The first education group contains couple whose education level is less than a bachelor degree. In the second group the wife has less than a bachelor's degree but her husband has at least a bachelor degree. The third group is wifes with at least a bachelor degree and husbands with an education below bachelor's level. The fourth group is couples where both have at least a bachelor degree. Finally, we distinguish between four geographic locations: Atlantic Canada, the Canadian Prairies and British Columbia, Ontario and Quebec.

While different types of grouping estimators have been used in the literature, we are somewhat constrained in our choice due to the relatively small numbers of groups and individuals within each group. ${ }^{17}$ We thus base our inference on the efficient wald estimator (EWALD) of Angrist (1991). This estimator uses weighted least squares on group data, controlling for different numbers of observations in different groups, and is among the most popular estimator in the category of regressions on grouped data. ${ }^{18}$

Our results using EWALD are presented in table 6 for the hours of work elasticities on the pooled data. We cannot reject the null hypothesis that the instruments are valid ( $\mathrm{p}$ value 0.00$)$. It shows own-elasticities to be higher than in table 4 while spouse and other income elasticities are slightly lower in absolute value. However, most importantly our key finding from the previous section remains intact. Elasticities estimated using net

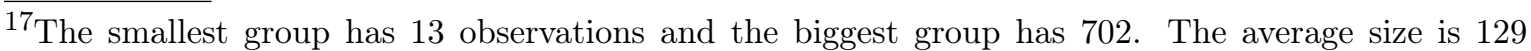
observations.

${ }^{18}$ Devereux (2007b) points out the increased likelihood of small-sample biases in EWALD when applied to synthetic cohort models of labour supply and Devereux (2007a) suggests alternative estimators including unbiased error-in-variables estimator (UEVE). As an additional robustness check, we also estimated this model and found similar results as with the EWALD.
} 
wages are half as large as those computed using gross wages. We conclude that the endogenous wages can not explain our results from the previous subsection.

To help alleviate concerns that EWALD estimator might be biased due to the relatively small numbers of individual in each group, we also estimated the model instrumenting the wage variables with dummy variables indicating in which decile the actual wage is. This is one of the method used by Blau and Kahn (2007) to take into account the endogeneity of the wage variables in the labour supply equation. The results from this estimation procedure, presented in Table 7, do not change our previous conclusion. In fact, these instruments are even stronger as seen from the lower estimated standard errors of the coefficients.

4.2. Results for different deciles. The previous section's results were based on a mean regression approach that looks only at the role of wages on hours of work at the mean. However, it could be that wages affect individual hours differently across the hours distribution (see for example Ribeiro (2001)). A way to overcome such a limitation is to adopt a quantile regression approach. Indeed, one may expect that at the low end of the hours distribution, workers could work more hours more easily, resulting in higher wage elasticities. Similarly, at the high end of the hours distribution, workers already work a lot; thus, we expect a smaller impact of changes in wages or non-labour income on hours of work.

Many of our explanatory variables do not vary significantly over the hours of work distribution. That is the case with education, activity limitation, union membership, and working in the public sector. However, for some variables the variation is quite large. Table 8 reports the quintiles for the marginal tax rate, the gross wage, whether a preschool child is present in the household, and the non-labour income. Most importantly, table 8 shows, as expected, that the marginal tax rate increases with hours of work. This means that the hourly wage also increases with hours of work over most of the distribution but starts declining for high levels of hours of work. This is consistent with low-wage individuals working part-time. Finally, table 8 shows that a higher percentage of wives with children work part-time and that those with high family non-labour income are more likely to work less hours.

Results of the quantile regression are summarized in figure 1 to 3 . These figures show the estimated hours of work elasticities over the hour's distribution at each decile. All figures include the estimated OLS elasticities as a grey solid line for comparison. The own-wage elasticities are shown in figure 1. The black solid line shows that the own-wage elasticity, computed without taking taxes into account, is as high as 0.6 
for married women working the fewest hours. Hereafter the elasticity declines rapidly down to 0.2 around the 4th decile, and decreases further to 0.11 at the median. For married women working the most, it is basically 0 starting at the 8 th decile. This shows that a change in a woman's own wages will need to be very large to induce a meaningful change in working hours. Even though the pattern in the elasticity over hours is generally as expected, the decline observed in the left part of the distribution is higher than expected. This implies much larger hours of work responses for wives working less hours.

Since wives at different points of the hours distribution face very different marginal tax rates, as shown previously in table 8, it is expected that repeating the quantile regression estimation procedure with net money amounts will change our conclusions significantly. Indeed, at the low-hours end of the distribution, we find that the ownwage elasticity falls from 0.6 to 0.3 when deflating wages by the average tax rate, and to 0.2 when using the marginal tax rate. This yields a similar conclusion to the one reached before, namely that the estimated labour supply responses are smaller once taxes are taken into account. This is also true for higher deciles. The point at which the estimated own-wage elasticity is zero is now the 6th decile when using average tax rates, and the 5th decile when using marginal tax rates. This implies that $50 \%$ of the wives in the sample would have essentially no labour supply response to a change in wage.

We also observe quite a bit of variation in the spouse-wage elasticity over the hours of work distribution, as shown in figure 2. The before tax spouse-wage elasticity is -0.25 for married women working the fewest hours. This is much larger than the mean spouse-wage elasticity of -0.06 from the OLS regression. The spouse-wage elasticity stays below -0.1 approximately until we reach the 3rd decile, but continues regressing toward zero up to the 4 th decile, where it reaches -0.05 . Thereafter the decline in the spouse-wage elasticity is less rapid, reaching zero starting at the 8th decile. In summary, these findings show that it would be misleading to ignore the heterogeneity of the wage effect along with hour's distribution when looking at both the own- and spouse-wages elasticities.

Finally, the non-labour income elasticities are shown in figure 3. The first thing to notice is that the after average tax and the after marginal tax lines are so close together that both lines are merged in the figure. Furthermore, the estimate from the OLS regression is 0 and therefore not shown in the graph. Even though the average other income elasticity is 0 , however, it is clear from the figure that there is also quite a bit of variation in the estimated elasticities across the hours distribution. As with 
the own- and spouse-wage elasticities, we find that the non-labour income elasticity is significantly lower for wives at the low end of the hours of work distribution, reaching zero between the 4 th or 5 th decile, depending on whether one uses net or gross income.

\section{Conclusion}

In this paper, we estimate own-wage, spouse-wage and non-labour income labour supply elasticities for Canadian wives using data from the SLID 1996-2005, and answer three related research questions. Our first research question was to evaluate how estimated elasticities vary when using net wages and income variables instead of gross money variables. We find that taking taxation into account yields significantly lower labour supply elasticities.

A second question was to evaluate if these elasticities dropped over time, as was recently reported in a series of studies using US data. Over a 10-year period from 1996-2005, we provide evidence that labour supply elasticities became closer to zero. However, the decreases were not as dramatic as those observed in the US, mainly because labour supply elasticities were smaller in Canada than in the US to begin with.

Finally, we also estimate labour supply over the hours of work distribution to investigate whether taking into account taxation has the same impact everywhere. We find that labour supply elasticities are much larger for wives working the fewest hours. In fact, once past the median number of hours of work, the estimated elasticities are basically zero for all three hours of work elasticities. Taking into account taxes by using net money amounts yields in general a lower hours of work threshold, at which point thereafter, the estimated elasticities are zero (except in the case of the non-labour income elasticities, where the threshold deciles are similar).

Overall, our results show that public policies now have, on average, less scope for influencing hours of work than 10 years ago. Still, the quantile results show that wives working less hours per week are more sensitive to changes in their own- or spousewages. Thus, if there is some scope in increasing working hours, the focus should be on these low-hours working wives. 


\section{REFERENCES}

Angrist, J. D. (1991). Grouped-data estimation and testing in simple labor-supply models. Journal of Econometrics 47, 243-266.

Blau, F. D. and L. M. Kahn (2007). Changes in the labor supply behavior of married women: 1980-2000. Journal of Labor Economics 25, 393-438.

Chaykowski, R. P. and L. M. Powell (1999). Women and the labour market: Recent trends and policy issues. Canadian Public Policy 15(1), S1-S25.

Cleveland, G., M. Gunderson, and D. Hyatt (1996). Female labour supply and fertility in Canada. The Canadian Journal of Economics 29(1), 132-148.

Devereux, P. J. (2004). Changes in relative wages and family labor supply. Journal of Human Resources 39(3), 696-722.

Devereux, P. J. (2007a). Improved errors-in-variables estimators for grouped data. Journal of Business and Economic Statistics 35, 278-287.

Devereux, P. J. (2007b). Small-sample bias in synthetic cohort models of labor supply. Journal of Applied Econometrics 22(4), 839-848.

Heim, B. T. (2007). The incredible shrinking elasticities: Married female labor supply, 1979-2003. Journal of Human Resources XLII(4), 881-918.

Hum, D. and W. Simpson (1991). Income Maintenance, Work Effort, and the Canadian Mincome Experiment. Economics Council of Canada: Ottawa.

Lefebvre, P. and P. Merrigan (2008). Child-care policy and the labor supply of mothers with young children: A natural experiment from Canada. Journal of Labor Economics 26(3), 519-548.

Meyer, B. D. (2002). Labor supply at the extensive and intensive margins: The EITC, welfare, and hours worked. American Economic Review: Papers and Proceeding, $373-379$.

Michalopoulos, C. and P. K. Robins (2000). Employment and child-care choices in Canada and the United States. The Canadian Journal of Economics 33(2), 435470 .

Milligan, K. (2008). Canadian Tax and Credit Simulator. Number Version 2008-1. Database, software and documentation.

Morissette, R. and F. Hou (2008). Does the labour supply of wives respond to husband's wages? Canadian evidence from micro and grouped data. The Canadian Journal of Economics 41(4), 1185-1210. 
Nakamura, A. and M. Nakamura (1981). A comparison of the labor force behavior of married women in the United States and Canada, with special attention to the impact of income taxes. Econometrica 49(2), 451-489.

Nakamura, A. and M. Nakamura (1983). Part-time and full-time work behavior of married women: A model with a doubly truncated dependent variable. The Canadian Journal of Economics 16(2), 229-257.

Nakamura, A. and M. Nakamura (1985). Dynamic models of the labor force behavior of married women which can be estimated using limited amounts of past information. Journal of Econometrics 27, 273-298.

Nakamura, A., M. Nakamura, and D. Cullen (1979). Job opportunities, the offered wage, and the labour supply of married women. American Economic Review 69, $787-805$.

Osberg, L. and S. Phipps (1993). Labour supply with quantity constraints: Estimates from a large sample of Canadian workers. Oxford Economic Papers 45(2), 269 291.

Phipps, S. (1991). Behavioural response to UI reform in constrained and unconstrained models of labour supply. Canadian Journal of Economics 14(1), 35-54.

Powell, L. M. (1997). The impact of child care costs on the labour supply of married mothers: Evidence from Canada. The Canadian Journal of Economics 30(3), $577-594$.

Powell, L. M. (2002). Joint labour supply and childcare choice decisions of married mothers. The Journal of Human Resources 37(1), 106-128.

Ribeiro, E. P. (2001, Mar). Asymmetric labor supply. Empirical Economics 26(1), $183-197$.

Robinson, C. and N. Tomes (1985). More on the labour supply of Canadian women. The Canadian Journal of Economics 18(1), 156-163.

Saez, E. and M. Veall (2005). The evolution of high incomes in Northern America: Lessons from Canadian evidence. American Economic Review 95(3), 831-849.

Sand, B. M. (2005). Estimating labour supply responses using provincial tax reforms. Working Paper University of British Columbia.

Smith, J. B. and M. Stelcner (1988). Labour supply of married women in Canada. The Canadian Journal of Economics 21, 857-870.

White, L. A. (2001). Child care, women's labour market participation and labour market policy effectivness in Canada. Canadian Public Policy / Analyse de Politiques 27(4), 385-405. 
Appendix A. Tables and Figures 
TABLE 1. Summary of Labour Supply Elasticity Estimates - Canadian Women

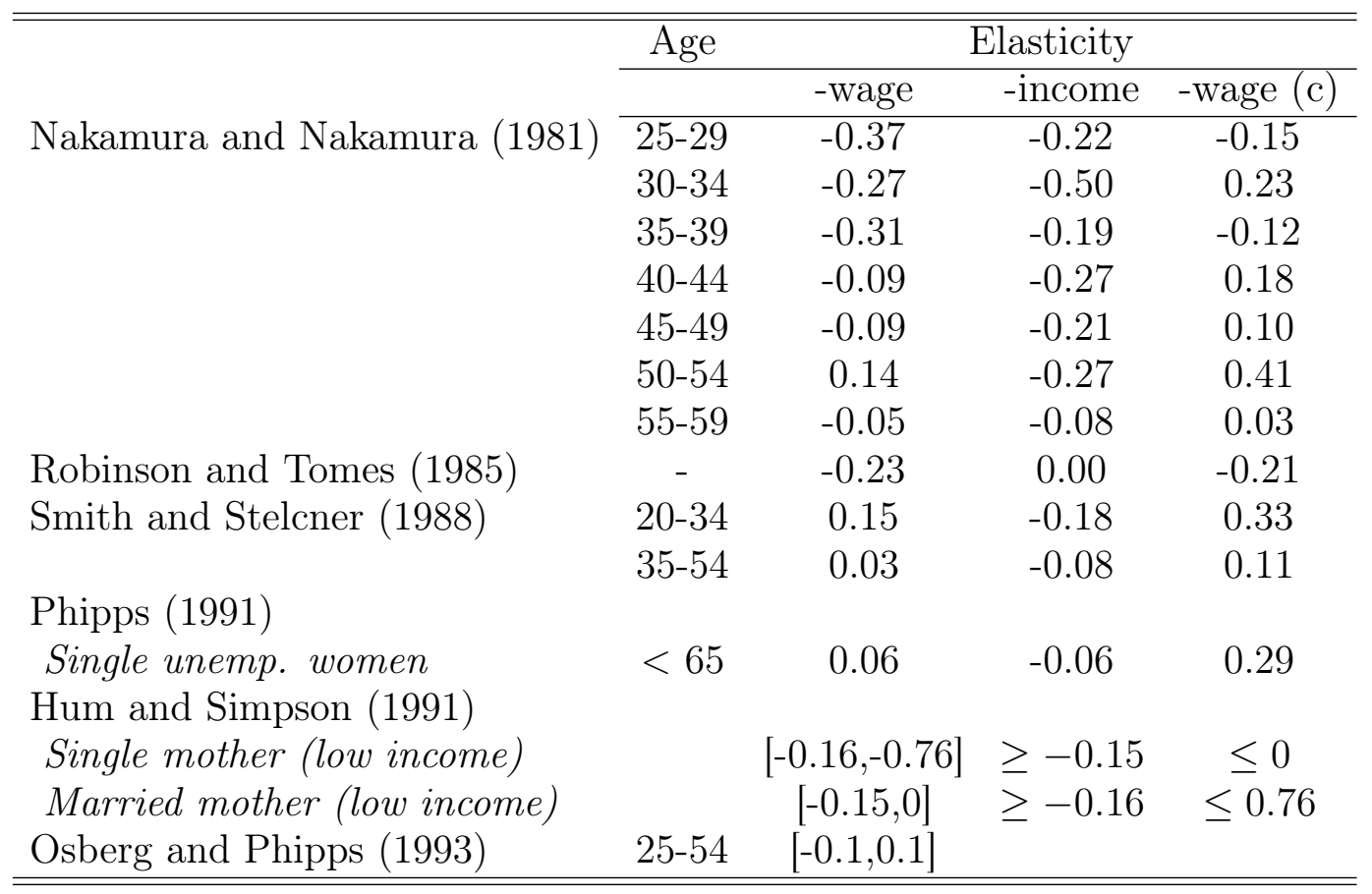


TABle 2. Summary Statistics - Hours, Wages and Income

\begin{tabular}{|c|c|c|c|c|c|}
\hline \multirow[b]{2}{*}{ Year } & \multicolumn{2}{|r|}{ Own } & \multicolumn{2}{|r|}{ Spouse } & \multirow{2}{*}{$\begin{array}{l}\text { Non-labour } \\
\text { income }\end{array}$} \\
\hline & Hours & Gross Wage Inc. & Hours & Gross Wage Inc. & \\
\hline \multirow[t]{2}{*}{1996} & 1,539 & 24,414 & 2,020 & 40,243 & 3,379 \\
\hline & $(646)$ & $(16,477)$ & $(537)$ & $(19,489)$ & $(10,969)$ \\
\hline \multirow[t]{2}{*}{1997} & 1,552 & 24,640 & 2,073 & 42,441 & 3,845 \\
\hline & $(659)$ & $(16,326)$ & $(557)$ & $(20,161)$ & $(17,101)$ \\
\hline \multirow[t]{2}{*}{1998} & 1,579 & 25,336 & 2,069 & 42,626 & 3,811 \\
\hline & $(646)$ & $(16,836)$ & $(539)$ & $(20,715)$ & $(13,621)$ \\
\hline \multirow[t]{2}{*}{1999} & 1,586 & 25,569 & 2,042 & 42,800 & 3,370 \\
\hline & $(616)$ & $(16,153)$ & $(530)$ & $(20,491)$ & $(22,844)$ \\
\hline \multirow[t]{2}{*}{2000} & 1,584 & 25,761 & 2,075 & 43,941 & 3,159 \\
\hline & $(641)$ & $(18,072)$ & $(561)$ & $(22,627)$ & $(12,543)$ \\
\hline \multirow[t]{2}{*}{2001} & 1,596 & 26,657 & 2,081 & 44,669 & 3,336 \\
\hline & $(643)$ & $(18,218)$ & $(562)$ & $(22,659)$ & $(11,624)$ \\
\hline \multirow[t]{2}{*}{2002} & 1,615 & 26,803 & 2,057 & 44,847 & 3,528 \\
\hline & $(616)$ & $(17,284)$ & $(539)$ & $(23,900)$ & $(15,178)$ \\
\hline \multirow[t]{2}{*}{2003} & 1,608 & 27,544 & 2,028 & 44,911 & 3,574 \\
\hline & $(611)$ & $(17,928)$ & $(518)$ & $(23,582)$ & $(17,381)$ \\
\hline \multirow[t]{2}{*}{2004} & 1,605 & 27,954 & 2,007 & 44,723 & 3,739 \\
\hline & $(613)$ & $(18,341)$ & $(503)$ & $(24,030)$ & $(17,448)$ \\
\hline \multirow[t]{2}{*}{2005} & 1,656 & 28,287 & 2,054 & 45,343 & 3,056 \\
\hline & $(602)$ & $(17,857)$ & $(549)$ & $(25,089)$ & $(11,495)$ \\
\hline \multirow[t]{2}{*}{ Total } & 1,600 & 26,912 & 2,045 & 44,216 & 3,481 \\
\hline & $(625)$ & $(17,735)$ & $(539)$ & $(23,080)$ & $(15,150)$ \\
\hline
\end{tabular}

Note. Standard deviations in parentheses. SLID 1996-2005. 
TABLE 3. Descriptive Statistics - Dichotomic Variables

\begin{tabular}{lccccccccccc}
\hline \hline Year & 1996 & 1997 & 1998 & 1999 & 2000 & 2001 & 2002 & 2003 & 2004 & 2005 & Total \\
\hline \multirow{2}{*}{$\begin{array}{l}\text { Labour market participation } \\
\text { Education }\end{array}$} & 81.4 & 83.5 & 83.7 & 81.8 & 83.5 & 84.9 & 85.4 & 86.4 & 86.7 & 84.8 & 84.1 \\
High school diploma & & & & & & & & & & & \\
Post-high school diploma & 48.7 & 36.1 & 34.5 & 36.5 & 34.3 & 31.9 & 32.5 & 30.9 & 28.3 & 28.7 & 33.6 \\
Baccalaureate & 47.5 & 49.5 & 50.4 & 48.5 & 49.6 & 50.6 & 49.8 & 51.6 & 52.0 & 52.0 & 50.0 \\
Higher studies & 10.5 & 11.0 & 11.1 & 11.5 & 12.6 & 13.5 & 13.9 & 14.0 & 15.3 & 15.5 & 12.7 \\
& 3.4 & 3.4 & 4.0 & 3.5 & 3.4 & 4.0 & 3.8 & 3.5 & 4.4 & 3.8 & 3.7 \\
No activity limitation & & & & & & & & & & & \\
Some preschool children & 30.1 & 29.5 & 28.6 & 27.4 & 26.9 & 26.3 & 12.6 & 27.1 & 27.7 & 25.3 & 26.4 \\
Union & 35.0 & 35.7 & 34.9 & 34.8 & 37.5 & 36.5 & 35.8 & 36.3 & 35.8 & 37.2 & 35.9 \\
Public & 23.7 & 24.0 & 25.6 & 31.6 & 32.8 & 33.1 & 32.8 & 32.9 & 33.2 & 35.6 & 30.1 \\
\hline \hline
\end{tabular}

Note. SLID 1996-2005. 
TABLE 4. Average Elasticities - 1996-2005

\begin{tabular}{ccccccc}
\hline \hline & \multicolumn{2}{c}{ Hours } & worked elasticities & \multicolumn{3}{c}{ Participation elasticities } \\
& Own & Spouse & Other & Own & Spouse & Other \\
\cline { 2 - 7 } No tax & $0.22^{* * *}$ & $-0.10^{* * *}$ & $-0.01^{* * *}$ & $0.02^{* * *}$ & $-0.06^{* * *}$ & $-0.00^{* * *}$ \\
& $(0.01)$ & $(0.01)$ & $(0.00)$ & $(0.00)$ & $(0.01)$ & $(0.00)$ \\
Avg tax & $0.09^{* * *}$ & $-0.08^{* * *}$ & $-0.01^{* * *}$ & $0.01^{* *}$ & $-0.02^{* * *}$ & $-0.00^{* * *}$ \\
& $(0.01)$ & $(0.01)$ & $(0.00)$ & $(0.00)$ & $(0.01)$ & $(0.00)$ \\
Mgn tax & $0.03^{* * *}$ & $-0.04^{* * *}$ & $-0.01^{* * *}$ & $0.01^{*}$ & $-0.03^{* * *}$ & $-0.00^{* * *}$ \\
& $(0.01)$ & $(0.01)$ & $(0.00)$ & $(0.00)$ & $(0.01)$ & $(0.00)$ \\
\hline \hline
\end{tabular}

Note. Includes wife's and husband's age, age squared, education and number of children under 6 years old. Includes province and year dummies. Bootstrapped standard error in parentheses. 
TABLE 5. Elasticities - 1996, 2000 and 2005

\begin{tabular}{lcccccc}
\hline \hline \multirow{3}{*}{1996} & \multicolumn{3}{c}{ Hours worked elasticities } & \multicolumn{3}{c}{ Participation elasticities } \\
\cline { 2 - 7 } & Own & Spouse & Other & Own & Spouse & Other \\
\hline No tax & $0.26^{* * *}$ & $-0.11^{* * *}$ & -0.00 & 0.02 & -0.04 & 0.00 \\
& $(0.03)$ & $(0.03)$ & $(0.00)$ & $(0.02)$ & $(0.02)$ & $(0.00)$ \\
Average tax & $0.08^{* *}$ & $-0.09^{* *}$ & $-0.01^{*}$ & 0.01 & -0.01 & 0.00 \\
& $(0.04)$ & $(0.03)$ & $(0.00)$ & $(0.01)$ & $(0.02)$ & $(0.00)$ \\
Marginal tax & 0.04 & -0.04 & $-0.01^{*}$ & 0.02 & -0.04 & 0.00 \\
& $(0.03)$ & $(0.02)$ & $(0.00)$ & $(0.02)$ & $(0.02)$ & $(0.00)$ \\
\cline { 2 - 7 } 2000 & Own & Spouse & Other & Own & Spouse & Other \\
\hline No tax & $0.27^{* * *}$ & $-0.09^{* * *}$ & -0.00 & 0.02 & $-0.07^{* * *}$ & 0.00 \\
Average tax & $(0.02)$ & $(0.02)$ & $(0.00)$ & $(0.01)$ & $(0.02)$ & $(0.00)$ \\
& $0.10^{* * *}$ & $-0.07^{* *}$ & -0.00 & 0.01 & -0.03 & -0.00 \\
Marginal tax & $(0.03)$ & $(0.03)$ & $(0.00)$ & $(0.01)$ & $(0.02)$ & $(0.00)$ \\
& 0.03 & -0.02 & -0.00 & 0.01 & $-0.05^{* *}$ & -0.00 \\
2005 & $(0.03)$ & $(0.02)$ & $(0.00)$ & $(0.01)$ & $(0.02)$ & $(0.00)$ \\
\hline No tax & Own & Spouse & Other & Own & Spouse & Other \\
& $0.19^{* * *}$ & $-0.06^{*}$ & -0.00 & 0.02 & $-0.08^{* *}$ & 0.00 \\
Average tax & $(0.02)$ & $(0.03)$ & $(0.00)$ & $(0.01)$ & $(0.03)$ & $(0.00)$ \\
& $0.07^{*}$ & -0.05 & -0.00 & 0.01 & -0.04 & 0.00 \\
Marginal tax & $(0.03)$ & $(0.03)$ & $(0.00)$ & $(0.01)$ & $(0.02)$ & $(0.00)$ \\
& 0.03 & -0.01 & -0.00 & 0.00 & -0.00 & -0.00 \\
& $(0.02)$ & $(0.02)$ & $(0.00)$ & $(0.01)$ & $(0.03)$ & $(0.00)$ \\
\hline \hline
\end{tabular}

Note. Includes wife's and husband's age, age squared, education and number of children under 6 years old. Includes province and year dummies. Bootstrapped standard error in parentheses. 
TABLE 6. Results using EWALD - 1996-2005

\begin{tabular}{|c|c|c|c|}
\hline & \multicolumn{3}{|c|}{ Hours worked elasticities } \\
\hline & Own & Spouse & Other \\
\hline \multirow[t]{2}{*}{ No tax } & $0.26^{* * *}$ & $-0.08^{*}$ & 0.00 \\
\hline & $(0.04)$ & $(0.04)$ & $(0.00)$ \\
\hline \multirow[t]{2}{*}{ Average tax } & $0.15^{* *}$ & -0.03 & 0.01 \\
\hline & $(0.05)$ & $(0.04)$ & $(0.00)$ \\
\hline \multirow[t]{2}{*}{ Marginal tax } & $0.13^{* * *}$ & -0.01 & 0.00 \\
\hline & $(0.03)$ & $(0.02)$ & $(0.00)$ \\
\hline
\end{tabular}

Note. Includes wife's and husband's age, age squared, education and number of children under 6 years old. Includes province and year dummies. Standard error in parentheses. 
TABLE 7. Results using deciles dummy IVs - 1996-2005

\begin{tabular}{|c|c|c|c|}
\hline \multirow[b]{3}{*}{ No tax } & \multicolumn{3}{|c|}{ Hours worked elasticities } \\
\hline & Own & Spouse & Other \\
\hline & $\begin{array}{c}0.24^{* * *} \\
(0.01)\end{array}$ & $-0.10^{* * *}$ & $\begin{array}{c}-0.00 * * * \\
(000)\end{array}$ \\
\hline Average tax & $\begin{array}{c}0.10^{* * *} \\
(0.01)\end{array}$ & $\begin{array}{c}-0.08^{* * *} \\
(0.01)\end{array}$ & $\begin{array}{c}-0.01^{* * *} \\
(0.00)\end{array}$ \\
\hline Marginal tax & $\begin{array}{c}0.05^{* * *} \\
(0.01)\end{array}$ & $\begin{array}{c}-0.04^{* * *} \\
(0.01)\end{array}$ & $\begin{array}{c}-0.01^{* * *} \\
(0.00)\end{array}$ \\
\hline
\end{tabular}

Note. Includes wife's and husband's age, age squared, education and number of children under 6 years old. Includes province and year dummies. Standard error in parentheses. 
TABLE 8. Selected characteristics at hours quintile

\begin{tabular}{lcccc}
\hline \hline Quintile & $\begin{array}{c}\text { Marginal } \\
\text { tax rate }\end{array}$ & $\begin{array}{c}\text { Gross } \\
\text { wage }\end{array}$ & $\begin{array}{c}\text { Non-labour } \\
\text { children }\end{array}$ \\
\hline 1 & 0.11 & 11.68 & 0.40 & $4,511.30$ \\
& $(0.24)$ & $(7.31)$ & $(0.49)$ & $(18,039.02)$ \\
2 & 0.23 & 13.38 & 0.33 & $4,041.93$ \\
& $(0.23)$ & $(7.64)$ & $(0.47)$ & $(15,158.57)$ \\
3 & 0.28 & 15.49 & 0.23 & $2,710.17$ \\
& $(0.34)$ & $(7.47)$ & $(0.42)$ & $(12,460.26)$ \\
4 & 0.32 & 16.86 & 0.19 & $2,816.81$ \\
& $(0.28)$ & $(7.19)$ & $(0.39)$ & $(16,189.10)$ \\
5 & 0.34 & 15.08 & $(0.20$ & $3,015.60$ \\
& $(0.20)$ & $(6.84)$ & $(0.40)$ & $(12,697.62)$ \\
\hline \hline
\end{tabular}

Note. Standard deviations in parentheses. 


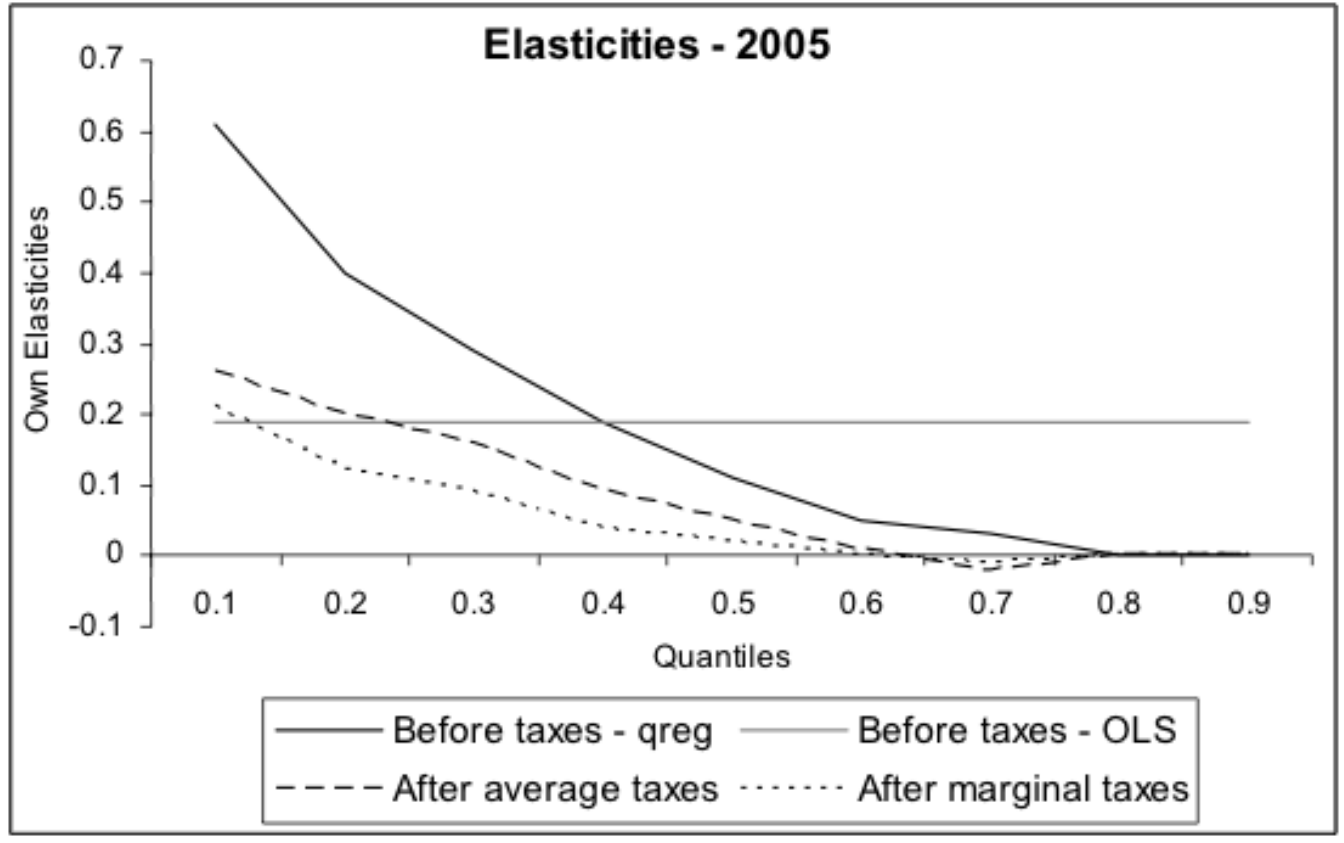

Figure 1. Own-Wage Elasticities 


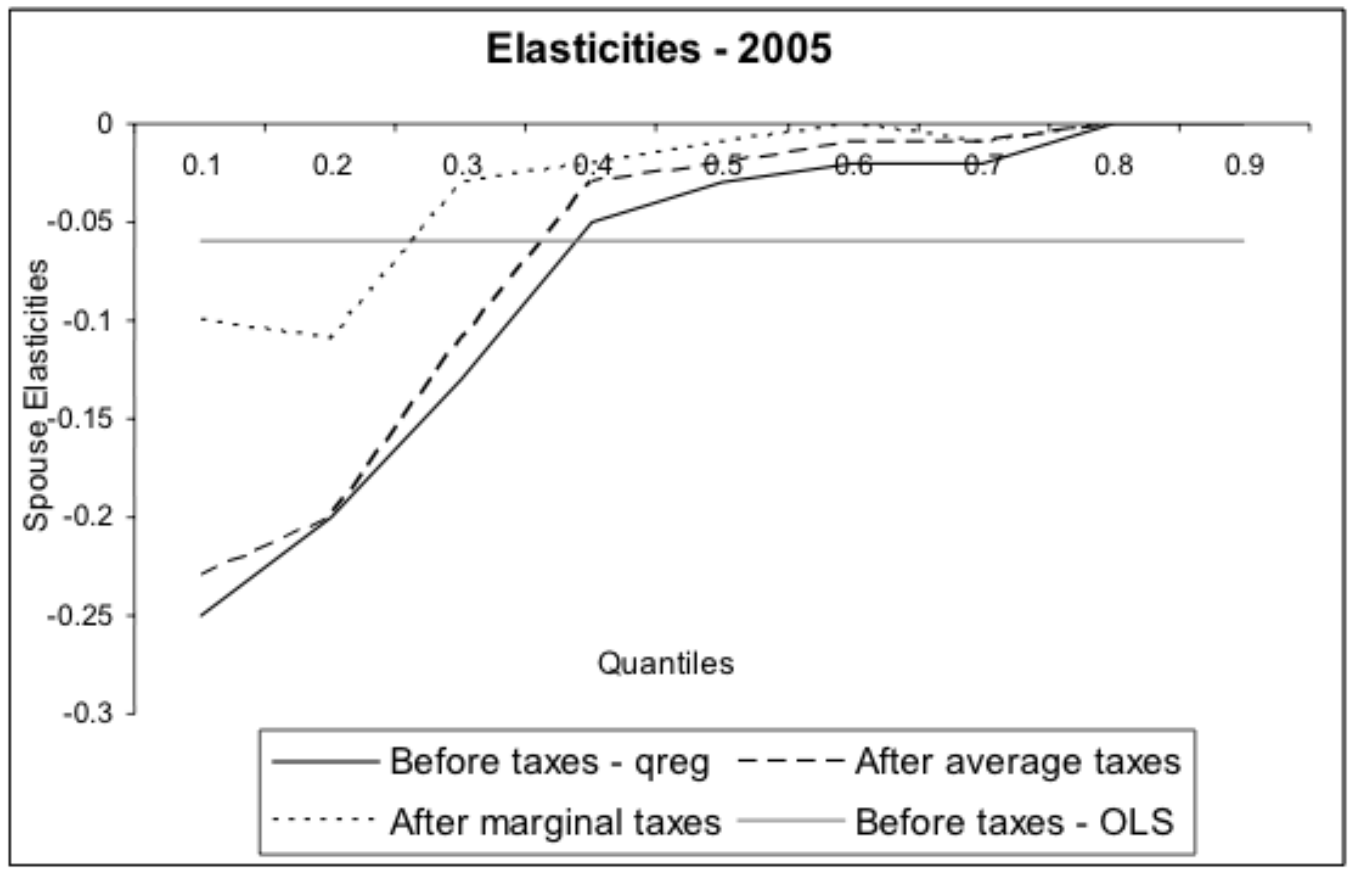

Figure 2. Spouse-Wage Elasticities 


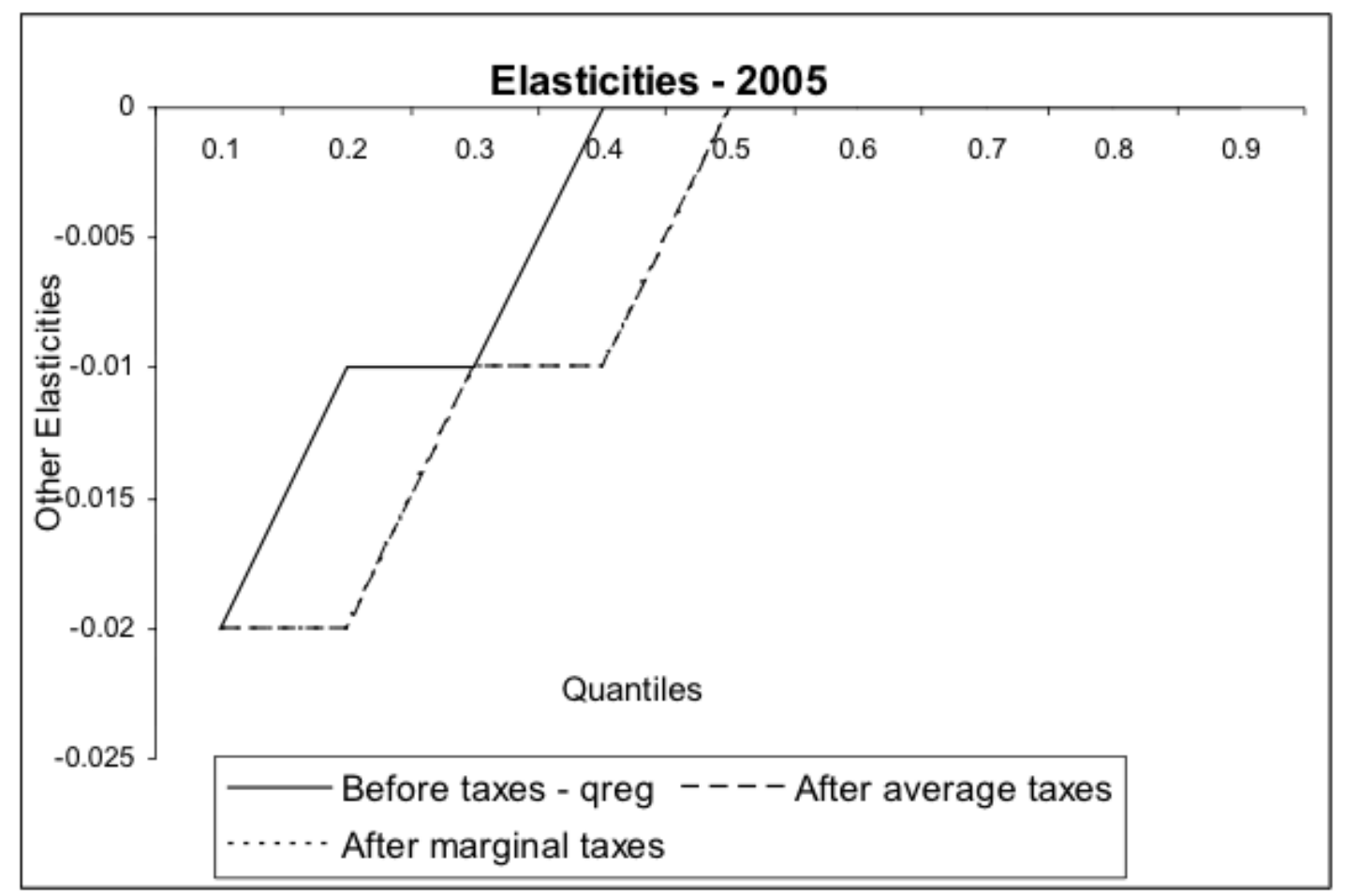

FiguRE 3. Non-Labour Income Elasticities 